\title{
O BEBÊ NASCE PELA BOCA: Voz, sujeito e clínica do autismo
}

\author{
Catão, I. (2009). O bebê nasce pela boca: Voz, sujeito e clínica do autismo. São Paulo: Instituto Langage.
}

\author{
Rosa Maria Marini Mariotto
}

Professora da Pontifícia Universidade Católica do Paraná (PUCPR), Doutora em Psicologia Escolar e do Desenvolvimento pela Universidade de São Paulo (USP), psicanalista, membro da Associação Psicanalítica de Curitiba, Curitiba, PR - Brasil, e-mail: rosamariotto@uol.com.br

Escrever um livro sobre autismo é sempre um desafio, pois o risco do lugar-comum é grande. Porém, a obra de Catão nos brinda com uma singular forma de apresentar e discutir esse tema tão instigante. Já na introdução, a autora mostra de qual perspectiva vai debater a questão. Ela lembra ao autor que, de modo geral, as discussões sobre o autismo destacam a fala dessas crianças, dando pouca ou nenhuma atenção a como elas ouvem. Não raro, as crianças autistas são diagnosticadas surdas ou são inicialmente encaminhadas para avaliações audiológicas, pois sua conduta dispersiva e desatenta face aos comandos da voz do outro, bem como a pobreza ou a inexistência discursiva despertam a preocupação dos pais e cuidadores.

Para a autora o autismo apresentaria, assim, "uma falha no circuito da invocação, não possibilitando à função psíquica da voz constituir-se como tal" (p. 225). Alcançar essa tese não se deu facilmente, e é justamente com esse trabalho de rastreamento teórico-clínico que Ines Catão brinda o leitor, em seu raciocínio analítico-investigativo.

O livro divide-se em três partes. Na primeira há uma nítida preocupação em oferecer ao leitor bases sólidas para a compreensão da estruturação psíquica. E, para isso, não apenas recorre aos textos de Freud e Lacan, mas convoca para a discussão Melanie Klein e Françoise Dolto, autoras que ainda fazem alguns analistas ditos lacanianos 'tremerem nas bases'. Ilustra de modo magistral todas essas considerações teóricas com um caso clínico.

A voz será o eixo da segunda parte do livro, ponto central de sua discussão. Aqui também Catão não se furta em trazer para a cena psicanalítica da pulsão invocante autores como Piera Aulagnier, que demonstra os três modos de metabolização do real, em que a voz do Outro tem função de unir a representação-coisa à representação-palavra, autores que se dedicam às pesquisas fetais, como também Didier Anzieu, que, com seu envelope sonoro demonstra de que modo o universo sonoro se antecipa ao visual na construção do Eu. A partir das três dimensões da voz - e para saber quais são, leia o livro! -, a autora confirma a voz materna - ou o manhês - como o "irresistível chamamento da voz da mãe que seduz o bebê. Este é o momento da alienação" (p. 173). Com isso posto, retoma o caso clínico, permitindo ao leitor acompanhar de que modo este canto da 
sereia não se enuncia nas palavras maternas e seus efeitos na montagem do psiquismo da criança, tema que se estende para a terceira parte do livro.

O que ouve uma criança autista? Para Catão não é o canto da sereia, mas sim uma voz inconstituída, que não a seduz para a subjetividade. Desse modo, o autista ouve mas não escuta, já que o ruído do Outro não se transforma em voz: "A criança autista sofre de uma surdez seletiva para a voz do outro (Outro). O evitamento seletivo da voz do outro (Outro) se instala antes de qualquer evitamento seletivo do olhar...” (p. 226).

E qual é o quinhão do analista na clínica com essas crianças? Conclui a autora que sua voz passa a ser moeda corrente e de valor na condução do trabalho clínico, na medida em que sua escuta deve permitir que a prosa lhe retorne com poesia, experiência mais próxima do inconsciente, aquela de fundação de um sujeito.

Aqui, uma escrita de sereia, que seduz o leitor do começo ao fim!

Recebido: 23/03/2009

Received: 03/23/2009

Aprovado: 04/05/2009

Approved: 05/04/2009 